\title{
Eternal Distance
}

\section{On the Significance of Window- and Cave Representations in Northern Romanticism}

\section{Zoltán Somhegyi}

\begin{abstract}
A BSTRACT Romanticism was the first period in art history that explicitly started to question the possibilities of a direct understanding of Nature and of achieving concrete and exact knowledge of it or of the "outside" world. In many cases, it can even be interpreted as a direct counter-tendency to the Enlightenment's concept of domestication and domination of Nature. In this paper it is argued that many window- and cave representations of Romanticism, especially in Northern Romanticism, are strongly connected with the differentiation of inside and outside, thus the main affirmation and message of these pictures is the inaccessibility of Nature, and this influences the composition, appearance and interpretation of the works.

KEYWOR DS Romanticism, nature, landscape, window representations, cave representations
\end{abstract}

The eighteenth century, as well as the turn of the eighteenth-nineteenth century was a period of intensive and significant changes in history, society, critical thought and naturally also in the arts. In 1965 Isaiah Berlin clearly and briefly described the "sudden" character of this radical shift of interest in his Mellon Lectures entitled "The Roots of Romanticism":

There is peace, there is calm, there is elegant building, there is a belief in the application of universal reason both to human affairs and to artistic practice, to morals, to politics, to philosophy. Then there is a sudden, apparently unaccountable, invasion. Suddenly there is a violent eruption of emotion, enthusiasm. People become interested in Gothic buildings, in introspection. Peoples suddenly become neurotic and melancholy; they begin to admire the unaccountable flight of spontaneous genius. ${ }^{1}$

This focus of interest influenced not only the style of art, but also the way of thinking about Nature, being one of art's main sources. The evaluation of Nature's beauty as well as the interpretation of the accessibility of Nature radically changed in the eighteenth-nineteenth centuries. The formerly dominable - or at least seemingly dominable - Nature became unknown, and the possibility of direct reach of it started to be questioned. Earlier examples of classical and classicising landscape painting, like the works of Joseph Anton Koch or Jacob Philipp Hackert - mostly representing harmonious Mediterranean forms - were mainly described with the aesthetic category of the beautiful, then right on the eve of Early 
Romanticism, the sublime started to be used to describe the non-classical, sometimes even anti-classical Northern landscapes, that were so frequently represented in Romantic landscape painting.

These phenomena, i.e. the shift of interest (e.g. "introspection", as Isaiah Berlin called it above), the discovery of the sublime aesthetics of anti-classical landscapes and the thematisation of the inaccessibility of Nature are most traceable in German and Nordic art. Naturally, we can sometimes observe similar approaches in the works of artists from other territories too, however, in most of the cases these examinations are not as central as in the oeuvre of their Northern colleagues. As it is well known, in other parts of Europe different issues, for example the interpretation of history or of actual political questions got more in focus, especially in Eastern Europe, where the Romantic ideas were often in the service of early forms of national(istic) awakening. One of the reasons for the sublime and inaccessible Nature being in central place in Northern painters' interest derives also from the fact that the non-harmonious Northern landscapes - non-harmonious compared to the Mediterranean - became a kind of national pride for these artists; pride as well as compensation, for the lack of Southern Arcadian forms. Since the analyses of the question about the diverse role Nature played in the art of different geographical areas and throughout the history of modern art could be the topic of much longer investigations, in this paper I concentrate on the area and time-period - Northern art around and after 1800 - that provide the best examples of artworks examining the question I am here interested in, i.e. the difficulties of a direct understanding of Nature.

As we have seen above, Northern Romantic landscapes often tend to be closer to the aesthetic category of the sublime than to that of the beautiful. But the other new feature, the difference in thinking of Nature's accessibility was also deeply influencing the appearance and composition of the works. In classical landscape painting we have a clear overview of the natural elements, of how the landscape representation is constructed. The vision presumes the direct access to these elements. A classical landscape is constructed and represented by a view that seems to be able to dominate the distance between the elements and also between the viewer and these elements - distance both in the literal and the metaphysical meaning. Even just a few decades before Romanticism, it still seemed possible to overcome distance, since the illusion of direct contact with Nature remained intact. Distance was only a mere physical feature, that man can beat - through the development of science, refinement of tools, better measurements etc. Distance in Nature seemed dominable, or even disappear. Alienation from 
Nature was still to be discovered. Even if the constructing elements of the landscape are far away, and amaze the viewer through their sublime splendour, height or frightening character, they are directly accessible, the wanderer can arrive to the furthest point, and theory and science can decipher all secrets. Direct access to Nature holds out the promise of dominating its forms, and we can see the compositional consequences of this in all those pictures where the view is constructed according to arbitrary - nonnatural but artistic and compositional - rules.

The dominating overview of classical landscape started to become a kind of "looking out", already during early Romanticism. The most definite Romantic experience is the unnaturalness of Nature, the impossibility of direct access to it. Not only was the wish of the Enlightenment of Nature's domination and domestication given up, but a new experience of distance was born. This distance is now infinite. We try to look out or to go out in Nature - from our new and "civilised" environment so much alienated from it. Just think of the C. D. Friedrich's Wanderer above the Sea of Fogs (c.1818, Hamburg, Kunsthalle) when contemplating the undiscoverable, fog-covered natural phenomena in emphasised and explicit city-clothing and with a walking stick. Still the essence of Nature always remains out of our reach.

In the case of Romantic landscape, the aim is to emphasise that the distance in Nature - mediated through the landscape - is undefeatably infinite, just as man's inner nature, often put in parallel with "outer" Nature during Romanticism. Looking out thus means not only experiencing the distance, but rather facing this inaccessibility. When we look out at something, we are somewhere inside, and something does not allow us to get directly to the object. Exactly this is the main affirmation in Romanticism. Landscape in Romanticism radically and basically changed both the concept and the representation of this infinite distance.

Therefore, when looking out, the distance is not real, but rather existential that clearly confronts the viewer with the obstacles that make inaccessible to arrive directly at the object. This newly discovered infinity was thus the elementary experiencing of the undefeatable distance manifested in Nature. As an artistic consequence of this experience, many artworks started to thematise the problems of getting real insight into the essence of Nature, especially through the emphasis of the difference of inside and outside.

The idea of the impossibility of direct contact with Nature is beautifully manifested in two seemingly different types of works, both often occur- 
ring in Northern art: window- and cave representations. At first, they seem complete opposites: in the case of window images we have only a small view of Nature, seen as a landscape through the window, while at images representing caves the whole picture represents a landscape, with a bigger or smaller "hole" on the surface. We can also notice a double opposition: at window-images we look from "inside" to "outside", while in the case of caves from the "outside" to "inside", and, as a second opposition, at windows we are in a closed place looking out at the open space, while at caves from the open into a closed one. Thus, the standing point, the direction of the view and the openness of the space are all oppositional, however the two types of images are still strongly connected. It is not the direction, but the way and aim of view that counts. In Romantic window paintings we literally have the representation of looking out - but here this looking out directly shows the impossibility of direct access to the viewed elements. The subject of the painting is not simply representing the view which is seen outside the window, but exactly this "outsideness" of this view, i.e. the fact that through the position of the viewer it is in opposition to the inside, and thus its unreachable feature is emphasised.

We have a similar phenomenon in the case of cave images, even though the direction of the view is the contrary, from the open outside to the closed and dark inside. But at both image-types the intention is the same: striving for direct experience and exact knowledge - and in both cases this understanding of Nature is obstructed. The view cannot serve knowledge, since the gradual and continuous overview is not guaranteed.

It is notable to see that in both cases Nature tempts to open itself for the viewer. We hope to gain access to its secrets by the vision, either by looking at its forms and elements through the window, or looking "inside" it, through the entrance of the cave, in order to discover the profound base and the essence of the ground, both literally or geologically - see the contemporary dispute over "Neptunism" and "Vulcanism" in Romanticism - and metaphorically too. In fact, this latter, i.e. metaphoric meaning is very complex, since a cave can symbolise many things, often even contradictory ones - or, as Werner Hofmann wrote: "Caves are ambivalent, they threaten and defend." ${ }^{2}$ Both in Christian and profane iconography a cave can have contradictory significance - in the former the birthplace of Jesus, dwelling of hermit saints but also the gate of Hell, while in the latter it can also refer to opposite meanings: birth and death, beginning and end, uterus and grave. And, as Werner Busch emphasised it, in the history and theory of architecture it may also refer to "the transit from underworld to earthly, from unshaped to formed, from Nature to Art". ${ }^{3}$ 
In fact, this allusion to (pre)history put the research of cave in the centre of interest in the eighteenth-nineteenth centuries. As Fritz Emslander affirmed it in his 2007 book on Italian cave-representations:

The condition of a new experience of the underworld was the discovery of deep layers of landscape and cities in the eighteenth century, that lead to a real enthusiasm towards caves. The spatial deepness was associated with the deepness of history, with the experience of time and with self-reflection. [...] Speleology that started to form itself as a scientific discipline allowed a rational approach of the underground territories that had been considered for a long time irrational. This rationalisation went hand in hand with the Enlightenment-driven demythologisation of the underworld. ${ }^{4}$

Nevertheless, there are divergent tendencies in the Enlightenment and Romanticism, as well as in the art from North and South of the Alps: the demythologisation seems more typical of the research of Italian caves, while in Northern Romanticism the symbolic significance of the cave remained important, even if this interpretation has shifted attention from religious symbols to personal existential references. However, naturally the division is not so rigid: there were Northern artists too - Carl Gustav Carus is the best example - who in their cave-representations successfully managed to combine a strong natural-scientific interest and the rendition of the almost mystic character of these underground territories.

On the other hand, when thinking of predecessors of the idea of looking out from the window - painted or drawn -, Alberti's famous description in his 1436 treatise On Painting automatically comes to our mind: "Here alone, leaving aside other things, I will tell what I do when I paint. First of all about where I draw, I inscribe a quadrangle of right angles, as large as I wish, which is considered to be an open window through which I see what I want to paint." ${ }^{5}$ In this way, a picture is made with the help of an imaginary window through which we can look out to the outside world. In Renaissance painting this opening could be a secondary element in the background of the painting - for example the open windows in the Sacra Conversazione paintings in Venetian Cinquecento. But during Romanticism, the window itself, functioning as a barrier between inside and outside could become the main motif on the image, often even without the representation of any human figures, and thus the subject of the image is exactly this opposition of inside and outside. What's more, the admired infinity of the open outside world becomes even more desirable when looking from the closed and limited inside. ${ }^{6}$ Therefore, a window will become both the condition of this opposition 
and the symbolic obstacle to reaching the long-desired harmonious unity with the world outside. And the canvas (or, mutatis mutandis, the paper) - through which we seem to gain insight, being formally parallel to the window - thus mediates a double transcript.

Besides investigating the former iconographic precedents and symbology of the motifs of cave and window, it is even more important to mention another parallel in the composition of these images that seem to refer directly to indirectness, and to express the conscious notice of the loss of direct access. A basic characteristic, or, better to say: condition in classical landscape painting is the gradual construction of the fore-, middle- and background, so that the eye of the viewer can easily and uninterruptedly overview the landscape, as we can observe in classical works, both North and South of the Alps, from the 16th century on. In the foreground we often find repoussoir figures to help the viewer in sensing the illusion of three-dimensionality of the picture, and this diagonal effect of these motifs could continue in the middle ground as well, with the help of roads or rivers that finally lead the eye to the background. The gradualness in organising the space was aided by the expert use of tones, light and focus, i.e. in the foreground forms are clear, detailed with sharp focus, often made of dark tones, that gently dissolve towards the background, where edges are blurred, contrasts are less intense and the tones of the forms are lighter. In this way it is clearly visible that in classical landscape all aspects: technical prerequisite, compositional structure, tonality and colouring, all this emphasised the gradual construction of the view. The viewer was able to gradually discover and domesticate the far landscape and distance of Nature through progressing by degrees.

Exactly here we have an important break of the pictorial tradition around 1800 that is best manifested in many cave- and window-representations. The most important feature is that one ground is completely or almost entirely missing. At window-images the foreground is lacking. Even if we have a tiny piece of the room, or we see part of the windowsill, this cannot be interpreted as a real foreground, only as an element to help the viewer to identify its position, from where he looks out. What's more, relatively often even the middle ground turns out to be unimportant, and the main focus is definitely on the background.

Similarly, in the case of cave-representations we again have a ground missing: the real background. The foreground is evidently visible, clearly detailed, and either here or in the middle ground we have the gate of the 
cave, but naturally we don't have a real background, since it is covered by the mountain that incorporates the cave itself. There can be a piece of sky above the mountain, but this cannot be considered as a real background, just as the room-corner or windowsill is not a real foreground. The real distance is inside, i.e. towards the deep layers of the cave that is obviously invisible, dark and mysterious.

Apart from describing the formal features of these images, the most important question seems to be why these motifs were represented like this? What do these compositional solutions refer to? If we accept that in Northern Romanticism the indirectness of arriving to Nature is in the focus of interest - both in philosophy and in the arts - then we can easily parallel these images with the Romantic strive for direct knowledge and the recognition of the failure of this aim. These pictures can clearly represent the impossibility of the direct and dominating view that view that seemed so natural and obvious only a couple of decades before Romanticism. Before 1800 the viewer stood firmly in his position, from where he could gradually observe the far ends of the landscape, and the space unfolded itself through fine degrees. Distance was not infinite, only a dominable physical feature, and space was not confusing and interrupted but harmonious or even structured. This calculable spatial harmony changed in Romantic art.

Consequently, as space and distance are not measurable and thus not dominable, the importance of the infinite grew. Infinite, as a "spatial" manifestation of sublime that overwhelms man could gain a symbolic character too: it is enough to recall The Monk by the Sea by Friedrich (1809, Berlin, Alte Nationalgalerie) to see how the spatial infinite could refer to the temporal one, and how this could symbolise the transcendental world, in opposition to man left alone with the elements. But it is not a simple alteration in the representation of distance, i.e. that the classical physical distance became infinite in Romanticism, but an essential change, where the infinite itself is transcendental and thus undefeatable, undiscoverable and unknowable. And exactly this we can see in the compositional structure of the cave- and window representations of Romanticism, since both show clearly the failure of knowledge: we may look out from the window to the landscape, but because of the lack of a real foreground we cannot get out to it, thus we can only face its infiniteness - a tool of the weak and failed attempt to defeat this infinite is put in focus in Carl Ludwig Kaaz' painting View from Grassi's Villa toward the Plauensche Grund near Dresden (1807, Private collection, Germany), where a small telescope is placed on the windowsill. And the same happens in cave representations, we can- 
not get real cognition of the deep layers of Nature and its secrets, even if we have the opening of the cave - that functions as a reverse window towards the profound depth - but due to the lack of a real background we again cannot have real cognition, we cannot know how far it reaches. The gradual, methodical discovery of knowledge fails, and we remain in the foreground, on the threshold of Nature's cognition.

Therefore it is quite likely that in both image-types the main significance is the impossibility of transition and the failure of gaining direct cognition, and besides this the investigation for further symbolic reading of the individual elements becomes secondary. Naturally, we can still analyse the motifs on the pictures (cave, window, trees, river and riverside, boat etc.), in the search for a potential ulterior and disguised meaning, but it is decisive to see that in the oeuvre of Caspar David Friedrich, Karl Blechen, Carl Gustav Carus or Johan Christian Clausen Dahl it is not about simply displaying elements that can be interpreted as symbols, but substantially influence the composition too. That is why instead of reading and decoding the individual motifs of the paintings, it seems to bring us closer if we concentrate on the general feature of the images that in its composition alludes to the impossibility of direct knowledge.

Another support in favour of our concept - i.e. that we should interpret caves and window in Romantic painting as representations of inaccessibility, and not as single symbolic motifs - is that the same motif, or even the same element could be used in different contexts, and this naturally would impede the direct symbolic decoding. Caspar David Friedrich for example sketched a cave during one of his trips in the Harz Mountain on June 27, 1811 (Vienna, Albertina) and then he used it several times in his oeuvre: next year in his Old Heroes' Grave (1812, Hamburg, Kunsthalle) and then almost ten years later again (1821, Greifswald, Pommersches Landesmuseum), without graves, and the motif appears again in a sepiadrawing (Copenhagen), whose dating is equivocal, for example Werner Sumowski dates it in the 1820 s, while Helmut Börsch-Supan at around 1838. The different context of the same motif indicates, that very likely there is not one single meaning of the cave and of the image, and that we cannot narrow the interpretation to a patriotic or religious meaning, ${ }^{8}$ or as a personal preparation for Friedrich's own passing - even if it could also work, especially if we accept the dating of Börsch-Supan of 1838, knowing that between Friedrich's stroke in 1835 and death in 1840 he did only smaller sepia works, no more oil paintings. Still we shall interpret the works from a wider perspective - as an aim to represent that the transcendent remains inaccessible and unknown. This approach helps 
us to keep the work's meaning more broad, open and rich, instead of getting satisfied with one clear deciphering. The motif of the cave in the Harz Mountain that appears altogether four times in Friedrich's oeuvre is not a blank symbol that can be used to indicate different meanings. Instead of analysing its significance in the different context, we shall concentrate on the feature that connects all these meanings: the reference to the unknown. What appears in the centre of Friedrich's images is the impenetrable depth of the cave.

However, we shall add to this that the cave can not only refer to a potential - and, as we have seen above, at the same time unsuccessful - attempt to get "insight" into the essence and working of Nature, but the motif can serve as a further reference to Plato's famous allegory too. We cannot be sure if it is a direct reference or mere a fortunate coincidence. For sure, Friedrich met several times personally with Friedrich Daniel Ernst Schleiermacher - perhaps as early as in 1798 , but then, for sure in 1810 and in 1818 - who was not only one of the most important philosophers of Romanticism, but who, right in these years was working on the translation of Plato's work, thus, no better source could Friedrich have to Ancient philosophy. ${ }^{9}$ On the other hand, as I argued above, Friedrich's artworks are never direct illustrations of philosophical, religious or patriotic ideas, even if there have always been attempts to interpret singular motives on his paintings and drawings from these perspectives. In any case however, the interpretation of the cave representations as pictorial manifestations of the inaccessibility to Nature's secrets is not in antagonism with the Platonic approach, on the contrary, since in both cases the cave will be an efficient aesthetic allusion to the epistemological difficulties of acquiring direct knowledge. The deep darkness of the cave - obviously in harsh contrast with the outside environment, from where the viewer attempts to observe it - obstructs the insight into the essence of Nature. Hence again we might recall another important feature in the Platonic allegory and in Neoplatonic discourse: the darkness as an elemental experience and hindering factor those who try to arrive at direct understanding have to face.

In this way, we can even say that the Romantic window- and cave images have a sort of meta-character: they don't (or not only) symbolise the transcendent, the other world or the unknown, but also the unknowable character of this unknown and the impenetrability of this beyond. By omitting a spatial shift - the foreground in window images and the background in cave representations - the impossibility of direct access to Nature is clearly emphasised. Caves' dark entrance - without the background that could define the perspective - shows that we are only at the 


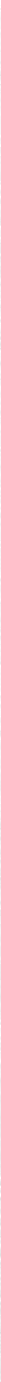

Caspar David Friedrich, Rock Cave in the Harz Mountains, c. 1838.

Sepia drawing, 34,5 × $43 \mathrm{~cm}$. HM The Queen's Reference Library, The Danish Royal Collections, BSI, 3a-3. 
beginning of cognition, and windows also serve to highlight the infinity, i.e. eternal distance of Nature that always remain infinite. As Josef Adolf Schmoll wrote in his essay on the history of the window-topos: "The window, with its frame and narrow wall-cutting that holds it serves as the required 'diaphragm' for viewing far." ${ }^{10}$ It is a compositional solution that subordinates every element and motif of the picture to the aim of alluding to the undefeatable distance of the infinite, and to focus on the unreachable character of this beyond.

The unreachable character of Nature was emphasised in two famous images from around 1811-1812 by Georg Friedrich Kersting, representing the painter Friedrich painting (Berlin, Alte Nationalgalerie). Even though they seem to be portraits of Friedrich, they are much more the representation of his painting method and ideals. These paintings clearly show Friedrich's understanding of the inaccessibility of Nature, by presenting the landscape painter turning away from his "model" by hiding the view from the studio window with shutters. As is known, covering the lower part of the studio window to get a less direct and more diffuse light only from above was a general working method among painters of the period, ${ }^{11}$ still we cannot disregard the further theoretical significance of this presentation. "Friedrich was of the opinion that all external things disturbed the inner world of pictures" - as we can read in Wilhelm von Kügelgen's affirmation when he visited Friedrich's studio, ${ }^{12}$ and this opinion is also manifested in Friedrich's working method: he collected elements of Nature on his wandering trips, and then used them to create real or imaginary landscapes - sometimes even re-using the same motif several times in different contexts, as we saw in the case of the cave from the Harz Mountain. Therefore, when presenting him in his almost entirely closed, narrow and empty studio, not only the difference of subject and object, inside and outside, closed and infinite is emphasised, but also Friedrich's scepticism of the possibility of understanding the real nature of Nature only by copying it or its forms. Nature's undominable infinity can only be understood if it is put in parallel to the infinity of the painter's own self. This leads to his wish to create inner landscapes. Thus, when using real elements collected during his trips, and creating the landscape painting in the solitude of his studio, this infinity resonates his own inner infinity, making the representation authentic. This was Runge's point of view too, influenced by Schelling's philosophy: "The human soul is the image of divine strength and the work of the artist is 'an image of the eternal source of his soul'." - as Klaus Lankheit quotes Runge's letter. ${ }^{13}$ For Friedrich, inner creation in art seems to be the only possible way of getting real cognition of Nature. 
Carl Gustav Carus - at least in the case of one of his paintings - is not so optimistic about this possibility. In his rendering of his studio's window (1823-24, Lübeck, Museum Behnhaus Drägerhaus) it is almost hard to decide if his intention was continuing or even consummating the Romantic critique of knowledge, or starting to become critical of this critique, in an intellectually satiric, almost parodic way? On the picture, the view from his window is covered with a painting(!). And, what's more, the painting is seen from the reverse of the canvas, thus not allowing the viewer of Carus' picture to see what is painted on this picture within the picture - or even if it is painted at all, or is just an empty canvas - although, as Sabine Rewald points out, since the artist's signature is visible upside down on the upper part of the canvas, it is more likely that it is a finished painting. ${ }^{14}$ And, not to forget, there is another painting on the easel too, but that is also turned back to the viewer. In this way we could have three representations of Nature, but none of them is visible: the one outside the window, the one painted on the larger canvas that is used to cover the window-view, and the one on the easel.

Because Carus is a landscape painter, we may think that the painting put in the window can represent a landscape that is an object, a piece of art put in opposition to the "outside" world, "showing" a painted landscape to Nature. The possible interpretation of this pictorial solution is really wide, Oliver Kase for example accentuates exactly this opposition of the painted Nature and the real one outside the studio, while Johannes Grave, in the catalogue of a recent exhibition of the painter highlights more Carus' embedded criticism of Alberti's concept of the painting as a window:

With his unusual image of the studio Carus brought a new, critical turn in the comparison of picture and window. His picture lets the viewer see less than we except at first. Picture and window will not approach each other as similar phenomena, much more will the canvas serve as a barrier to the view, against the window. In the eye of the viewer, the verso of the wedge-frame shows unmistakably that the image is first a material, flat object, before anything can appear on it. ${ }^{15}$

Nevertheless, even if there is difference in where Kase and Grave put the focus in their interpretation, the main intention of Carus seems obvious: it is the picture itself that is and serves as an obstacle of the view and thus of knowledge.

In this way, Carus' viewpoint here diverges from Friedrich's when stating that our knowledge of Nature cannot be aided through art, and we get even twice as far from real Nature: not only standing "inside", having 
the window impeding us of direct access to it, but even being prisoners of our own attempt of representing it.

Dedicated to Werner Busch, expressing my gratitude for all the inspiring conversations about Romanticism.

\section{Notes}

1. Isaiah Berlin, The Roots of Romanticism (Princeton, New Jersey: Princeton University Press, 2001), 6.

2. "Höhlen sind ambivalent: sie bedrohen und bergen." Werner Hofmann, Caspar David Friedrich (Munich: Prestel Verlag, 1974), 51.

3. “...die Grotte verkörpert in der Architekturgeschichte und Architekturtheorie den Übergang vom Unteriridischen ins Irdische, vom Ungestalteten ins Gestaltente, von Natur in Kunst." - Werner Busch, "Carus auf Staffa. Mythologie und Geologie," in Carl Gustav Carus: Wahrnehmung und Konstruktion, ed. Petra Kuhlmann-Hodick, Gerd Spitzer and Bernhard Maaz (Munich: Deutsche Kunstverlag, 2009), 187.

4. "Voraussetzung für eine neue Wahrnehmung des Unterirdischen war die Entdeckung der Tiefendimension der Landschaft und der Städte im 18. Jahrhundert, die zu einer wahren Höhlenbegeisterung führte. Die räumliche Tiefe wurde mit der Tiefe der Geschichte, mit Zeiterfahrung und Selbstreflexion assoziiert. [...] Die sich als Wissenschaft formierende Speläologie ermöglichte einen rationalen Zugang zu dem lange tabuisierten und irrational gedeuteten Bereich des Subterranen. Diese Rationalisierung ging mit dem aufklärerischen Prozeß der Entmythisierung des Unterirdischen einher." Fritz Emslander, Unter klassischem Boden: Bilder von Italiens Grotten im späten 18. Jahrhundert (Berlin: Reimer, 2007), 273.

5. Leon Battista Alberti, On Painting, trans. John R. Spencer (New Haven: Yale University Press, 1966), 55-56.

6. See also Eberhard Ruhmer, "Innenraum und Landschaftsraum. Bemerkungen zur Interieur-Landschaft der Romantik", in Münchner Landschaftsmalerei 18001850, ed. Armin Zweite; Cat. exhib. Städtische Galerie im Lenbachhaus, Munich, March 8-May 20, 1979 (Munich: Lenbachhaus, 1979), 149-58, especially 150.

7. About the question of dating the drawing see the catalogue of Friedrich's exhibition in Stockholm: Torsten Gunnarsson, Caspar David Friedrich: Den besjälade naturen, Cat. exhib. Nationalmuseum, Stockholm, October 2, 2009January 10, 2010 (Stockholm: Nationalmuseum, 2009), 139.

8. As it was proposed by Börsch-Supan, interpreting the first version as patriotic and the second as religious: "il contenuto patriottico viene però sostituito da 
un'allegoria religiosa." Helmut Börsch-Supan, L'opera completa di Caspar David Friedrich (Milan: Rizzoli Editore, 1976), 98.

9. See more on these meetings in Werner Busch, Caspar David Friedrich: Ästhetik und Religion (Munich: C. H. Beck, 2003), 74-75, and Thomas Noll, Die Landschaftsmalerei von Caspar David Friedrich: Physikotheologie, Wirkungsästhetik und Emblematik; Voraussetzungen und Deutung (Munich: Deutscher Kunstverlag, 2006), 60-62.

10. "Das Fenster bildet mit seinem Rahmen und dem schmalen Wandausschnitt, in dem es sitzt, die erwünschte 'Blende' für die Fernsicht.” Josef Adolf Schmoll gen. Eisenwerth, "Fensterbilder: Motivketten in der europäischen Malerei", in Beiträge zur Motivkunde des 19. Jahrhunderts, ed. Ludwig Grote (Munich: Prestel Verlag, 1970), 13-165; quotation from 113.

11. See more on this question in Busch, Caspar David Friedrich, 20-21.

12. Quoted in Sabine Rewald, Rooms with a View: The Open Window in the 19th Century, Cat. exhib.: The Metropolitan Museum of Art, New York, April 5-July 4, 2011 (New Haven: Yale University Press, 2011), 74.

13. Klaus Lankheit, "Early Romanticism and the Fundamentals of "non figurative' Painting", in Facing Mental Landscapes: Self-Reflections in the Mirror of Nature, ed. Manfred Milz (Hildesheim: Georg Olms Verlag, 2011), 101. (Lankheit’s text was first published in German in 1951, as "Die Frühromantik und die Grundlagen der 'gegenstandlosen' Malerei", Neue Heidelberger Jahrbücher 20 (1951): 55-90. English translation by Giles Bennett.)

14. Rewald, Rooms with a View, 52.

15. "Mit seinem ungewöhnlichen Atelierbild gab Carus dem Vergleich von Bild und Fenster eine neue, kritische Wendung. Sein Bild lässt den Betrachter weniger sehen, als man zunächst erwartet. Bild und Fenster werden nicht als ähnliche Phänomene einander angenähert, vielmehr wird die Leinwand als Blickbarriere gegen das Fenster gewendet. Mit der Rückseite des Keilrahmens wird dem Betrachter unmissverständlich vor Augen geführt, dass das Bild in erster Linie ein materieller, flächiger Gegenstand ist, bevor im Bild etwas zur Erscheinung kommen kann." Quoted from Johannes Grave's analyses of the painting in the catalogue volume of the Carus-exhibition of 2009 in Berlin: Petra KuhlmannHodick, Gerd Spitzer and Bernhard Maaz, Natur und Idee, Cat. exhib. Staatliche Kunssammlungen Dresden, June 26-September 20, 2009; Alte Nationalgalerie Berlin, October 9, 2009-January 10, 2010 (Munich: Deutsche Kunstverlag, 2009), 86-87. See also Grave's opinion against Kase's in the essay-book accompanying the exhibition: Johannes Grave, "Der 'fixierte Blick': Bildtheoretische Implikationen des Fensterbildes bei Carl Gustav Carus", in Carl Gustav Carus: Wahrnehmung und Konstruktion, ed. Petra Kuhlmann-Hodick, Gerd Spitzer and Bernhard Maaz (Munich: Deutsche Kunstverlag, 2009), 201-10, especially 204. 